\title{
The expression and regulation of Sex combs reduced protein in Drosophila embryos
}

\author{
Peter D. Riley, Sean B. Carroll' ${ }^{1}$, and Matthew P. Scott
}

Department of Molecular, Cellular and Developmental Biology, University of Colorado at Boulder, Boulder, Colorado 803090347 USA

\begin{abstract}
Homeotic genes are expressed in spatially precise patterns during Drosophila development to control segmental differentiation. The Sex combs reduced (Scr) gene of the Antennapedia gene complex is involved in the determination of the labial and prothoracic segments of the embryo. To study both the wild-type pattern of Scr expression and the regulatory relationships of $S c r$ to other regulatory genes, an antibody probe that detects the Scr protein was prepared. We find that the Scr gene product is expressed in a dynamic pattern over the course of embryogenesis, beginning in the ectoderm in parasegment 2 while the germ band is elongated and extending to parasegment 3 during the completion of germ band shortening. The locations of Scr protein correlate well with the parts of the embryo that are altered in $\mathrm{Scr}^{-}$mutants. After head involution occurs, Scr protein is also expressed in the ganglion corresponding to parasegment 2 of the ventral nervous system. The precise spatial expression of $S c r$ is attained through regulation by both homeotic genes and segmentation genes. The lack of proper Antennapedia or Polycomb gene function causes ectopic Scr protein expression. Mutations in the segmentation genes fushi tarazu, hunchback, Krüppel, and giant alter the spatial pattern of Scr expression.
\end{abstract}

[Key words: Drosophila; Scr gene; Antennapedia complex; homeotic genes]

Received May 27, 1987; revised version accepted

The fate of individual cells during Drosophila development is determined, in part, by the action of homeotic genes. The precise spatial patterns of homeotic gene expression underlie the differentiation of the segments of the larva and adult and change as development proceeds. Diversification of the abdominal segments was proposed by Lewis (1978) to result from the differential expression along the antero-posterior axis of the embryo of a cluster of homeotic genes called the bithorax complex (BX-C). Lewis' hypothesis has been supported experimentally by the observation that $\mathrm{BX}-\mathrm{C}$ gene products are localized predominantly to the areas of the embryo which are perturbed when the genes are mutated. For example, the BX-C gene Ultrabithorax (Ubx) was shown by genetic analyses to be a locus that controls the identity of the posterior thorax and anterior abdomen (Lewis 1978; Sanchez-Herrero et al. 1985). High-level RNA transcription of the $U b x$ gene is restricted to this same region (Akam 1983; Akam and Martinez-Arias 1985; Harding et al. 1985). Another cluster of homeotic genes, the Antennapedia complex (ANT-C), controls thoracic and head segmentation (Kaufman et al. 1980). The ANT-C genes Antennapedia (Antp), Sex combs reduced (Scr), and Deformed $(D f d)$ control the identities of the meta- and mesothorax, the prothorax and labium, and particular re-

'Present address: Laboratory of Molecular Biology, University of Wisconsin-Madison, Madison, Wisconsin 53706 USA. gions of the head, respectively (Kaufman et al. 1980; Wakimoto and Kaufman 1981; Regulski et al. 1987). The transcripts from these genes have been detected in the corresponding segmental primordia in the embryo (Levine et al. 1983; Harding et al. 1985; Kuroiwa et al. 1985; Martinez-Arias 1986; Chadwick and McGinnis 1987; Martinez-Arias et al. 1987).

We have studied the expression and regulation of the Scr homeotic gene. Scr controls the differentiation of cells in a region anterior to the cells controlled by Antp (Kaufman et al. 1980; Lewis et. al. 1980; Wakimoto and Kaufman 1981; Struhl 1982, 1983; Sato et al. 1985). Most $S c r$ alleles are lethal when homozygous, the embryos dying during late embryogenesis. The loss of $\mathrm{SCr}^{+}$ function results in two oppositely oriented homeotic transformations in the embryo: labial into maxillary segments and T1 into T2 (Wakimoto and Kaufman 1981). Similar transformations are seen in adults having reduced Scr function (Kaufman and Abbott 1984).

Scr RNA expression occurs in the same regions of the embryo that are disrupted in $\mathrm{Scr}$ mutant embryos. In situ hybridization of RNA to embryo sections has revealed the presence of $S c r$ transcripts in the embryonic mesoderm and ectoderm, primarily in the posterior maxillary through anterior T1 segments (Kuroiwa et al. 1985; Martinez-Arias et al. 1987), also designated parasegments (PS) 2 and 3 (Martinez-Arias and Lawrence 1985). In the embryonic central nervous system, Scr 
RNA was detected in the posterior region of the subesophageal ganglion (Harding et al. 1985; Kuroiwa et al. 1986) or, more precisely designated, PS 2 of the embryonic nerve cord (Martinez-Arias et al. 1987).

How are the restricted domains of homeotic gene expression generated during development? It appears that the patterns of homeotic gene expression are initially controlled by another class of genes crucial in development, the segmentation genes. These genes are the earliest-acting genes in the zygote and have been classified into three categories (Nüsslein-Volhard and Wieschaus 1980). Mutations in "gap" loci affect the development of large, mostly continuous blocks of segments. The broad units defined by gap loci are then refined by the actions of "pair-rule" loci, which control the specification of alternating metameric units. Finally, "segment polarity" loci direct pattern formation within every segment. The pair-rule genes and the segment polarity genes whose patterns of expression have been analyzed are expressed in transverse stripes (Hafen et al. 1984a; Carroll and Scott 1985; DiNardo et al. 1985; Fjose et al. 1985; Ingham et al. 1985a; Kornberg et al. 1985; Bopp et al. 1986; Harding et al. 1986; Kilchherr et al. 1986; Macdonald et al. 1986; Frasch et al. 1987). These stripes of gene product presumably provide information in repeating units at one- or two-segment intervals, leading to specific determination of cell fates along the anteriorposterior axis of the embryo. The actions of the gap loci, which are expressed in broad regions (Knipple et al. 1985; Jäckle et al. 1986; Tautz et al. 1987), appear to define different regions of the embryo, providing information in nonrepeating units. Thus, differential action of homeotic genes along the anterior-posterior axis could be regulated both by segmentation genes that set up the repeating metameric units of the Drosophila body plan and by segmentation genes that define the metameres as different from each other. Insight into the mechanism of action of these genes may be provided by the observations that some of the segmentation genes have been shown to be critically important for the correct spatial expression of homeotic genes (Ingham and MartinezArias 1986; Ingham et al. 1986; White and Lehmann 1986).

The patterns of homeotic gene expression persist long after many of the segmentation genes have ceased to be expressed. Interactions between ANT-C and BX-C genes themselves seem to be at least part of the mechanism through which homeotic gene expression remains spatially restricted throughout embryogenesis. It has been shown that some of the genes in the BX-C and ANT-C interact, with posteriorly acting genes regulating more anteriorly acting genes (Hafen et al. 1984b; Struhl and White 1985). In addition, homeotic genes that reside outside either complex, such as Polycomb $(P c)$ or extra sex combs (esc), can regulate ANT-C and BX-C gene expression (Lewis 1978; Struhl 1981b, 1983; Duncan 1982; Beachy et al. 1985; Sato and Denell 1985; Carroll et al. 1986a; Wedeen et al. 1986; Capdevila et al. 1986).

We have prepared an antibody directed against a recombinant form of the $S c r$ protein product. Immunofluorescence analysis, using the antibody to probe whole- mount preparations of wild-type and mutant embryos, permits excellent resolution of the expression pattern of $S c r$ protein. The results indicate that $S c r$ protein is expressed in a pattern that changes during the course of embryogenesis, a pattern consistent with the known $S c r$ functions. We also observe that the wild-type $S c r$ protein distribution is dependent upon the proper functions of several segmentation genes and the homeotic genes Antp and Pc.

\section{Results}

Isolation of an Scr cDNA clone, expression of Scr protein in $\mathrm{E}$. coli, and production of antibodies

The location of the Scr gene in the ANT-C has been defined by mapping chromosome breakpoints (Garber et al. 1983; Scott et al. 1983; Kuroiwa et al. 1985/ and by transcript mapping (Kuroiwa et al. 1985). The results (Fig. 1a) show that $S c r$ has at least two exons, at ${ }^{+} 25-+28$ and $+44-+45$ on the physical map using the coordinates of Scott et al. (1983). RNA probes derived from both exons have been used in in situ hybridizations; they hybridize to transcripts in PS2 and 3 (Harding et al. 1985; Kuroiwa et al. 1985; Martinez-Arias et al. 1987). The ${ }^{+} 25-{ }^{+} 28$ exon contains a homeobox, a DNA sequence that is conserved among many segmentation homeotic genes (McGinnis et al. 1984a; Scott and Weiner 1984). The Scr homeobox sequence encodes a protein "homeodomain" closely related to the corresponding Antp and $U b x$ sequences (Kuroiwa et al. 1985; Laughon et al. 1985). The $+44-+45$ exon contains an "M repeat" (McGinnis et al. 1984b) that consists of repeating CAA and CAG repeats (Laughon et al. 1985). In addition, a transcript that may be related to $S c r$, the " $\mathrm{X}$ " transcript, is detected with probes from ${ }^{+} 80$ (Kuroiwa et al. 1985).

A $3.9 \mathrm{~kb}$ cDNA clone containing most of the sequence of the $+25-+28$ and $+44-+45$ exons was isolated (see Materials and methods) from a library prepared from 3-12 hr embryonic RNA (the library was generously provided by Drs. L. Kauvar and T. Kornberg). The cDNA is approximately the same length as the major $\mathrm{Scr}$ mRNA detected on RNA blots (Harding et al. 1985; Kuroiwa et al. 1985). The restriction map of the cDNA (Fig. $1 b$ ) agrees with a published cDNA map (Kuroiwa et al. 1985 ), but the present clone is approximately $200 \mathrm{bp}$ longer at each end.

To construct a lac Z-Scr gene fusion, a 1.9-kb SacII$X$ hol fragment of the cDNA containing the homeobox and most of the more $5^{\prime}$ sequence (Fig. $1 \mathrm{~b}$ ) was cloned into the pUR 290, 291, and 292 lac fusion vectors (Ruther and Müller-Hill 1983). Insertion of the Scr cDNA fragment into the polylinker cloning site of the pUR vectors places the insert immediately $3^{\prime}$ to the inducible lac $Z$ gene. Since each pUR vector joins the insert to $l a c Z$ in one of the three possible reading frames, only one construction is expected to yield a fusion protein with $S c r$ in the correct reading frame. The three constructions yielded $\beta$-galactosidase-containing proteins of $140 \mathrm{kD}, 116 \mathrm{kD}$, and $126 \mathrm{kD}$, respectively (data not shown). The proteins produced, as revealed by Coo- 
Riley et al.

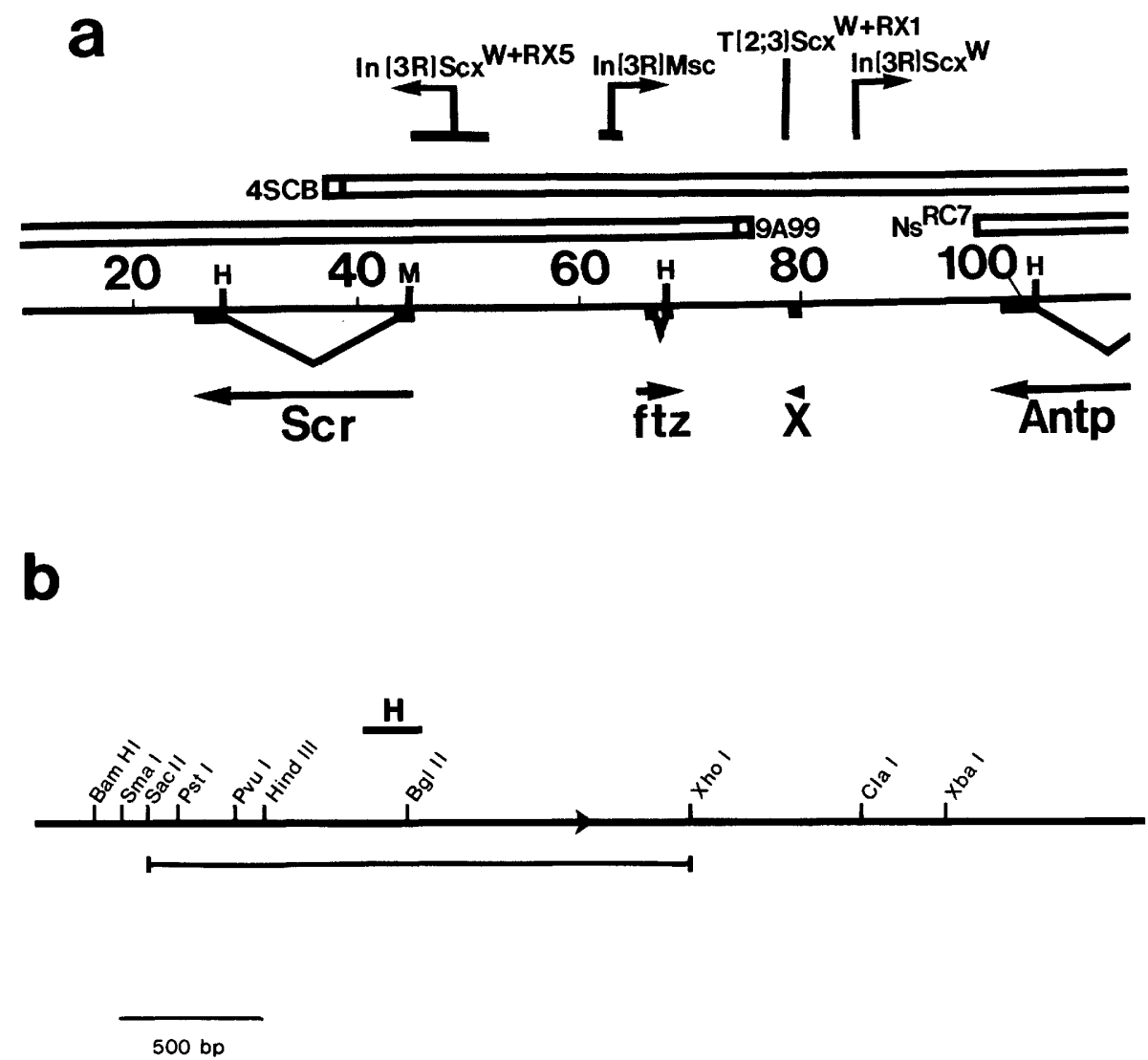

Figure 1. Map of the $S c r$ region of the ANT-C and the Scr cDNA clone. (a) Genomic DNA map. Coordinates (in kilobases) are as in Scott et al. (1983). Only the 3' end of the Antennapedia(Antp) transcription unit is shown. The fushi tarazu (ftz) transcription unit and the transcript $X$ (of unknown function) (Kuroiwa et al. 1985) are also shown. The boxed deletions indicate DNA that is absent in those mutants (data from Garber et al. 1983 and Kuroiwa et al. 1985). $D f(3 R) N s^{+R C 7}$ deletes Antp function but not Scr function (Struhl 1981). $D f(3 R) 9 A 99$ removes $S c r$ but not $A n t p$ function, and $D f(3 R) 4 S C B$ removes both $S c r$ and $A n t p$ function. $\operatorname{In}(3 R) S c x^{W}$, a $50-\mathrm{kb}$ inversion (Scott et al. 1983) is a recessive lethal allele of Antp and also partially inactivates Scr function (Lewis et al. 1980; Hazelrigg and Kaufman 1983). Two derivatives of $S c x^{W}$, the translocation $S c x^{W+R X 1}$ and the inversion $S c x^{W+R X 5}$, have chromosome breakpoints as shown (Scott et al. 1983). Both of these mutants contain the $50-\mathrm{kb} \mathrm{Scx}^{W}$ inversion as well as their additional rearrangements, and both are stronger $S c r$ lethals than the original $S c x^{W}$ mutation (Hazelrigg and Kaufman 1983). The directions of transcription are shown by the arrows. Exons and splices are indicated by bars below the coordinate map, joined by light lines. Homeoboxes (H) and $M$ (or CAG) repeats (M) are also shown. Only the $3^{\prime}$ end of the Antennapedia transcription unit is shown. (b) Restriction map of the Scr cDNA clone used to produce $\beta$-galactosidase fusion proteins. The clone is $4 \mathrm{~kb}$ long and contains nearly all of the two exons shown in Fig. la. The underlined part of the cDNA, from the SacII site to the XhoI site, was used to construct the lacZ fusion (see Materials and methods). The BgIII site is located in the homeobox (Laughon et al. 1985; Kuroiwa et al. 1985) as shown.

massie staining in induced cells, are shown in Figure 2A. Only the $140-\mathrm{kD}$ protein contained both $\beta$-galactosidase and homeodomain determinants, as identified with antibodies directed against $\beta$-galactosidase (Fig. 2B) or the homeodomain (Fig. 2C) (Carroll et al. 1986b).

The $140-\mathrm{kD}$ Scr- $\beta$-galactosidase hybrid protein was partially purified (as described in Materials and methods) and used to immunize rabbits. Antibodies directed against the $S c r$ portion of the fusion protein were purified from the sera using affinity chromatography as described by Carroll and Scott (1985) and in Carroll and Laughon (1987). The specificity of the anti-Scr antibodies was determined by an immunoblotting assay against induced and uninduced $E$. coli lysates of the pUR-Scr-plasmid-bearing strain. The affinity-purified antibody reacts only with the $S c r$ determinants of the intact fusion protein and its degradation products and not with $\beta$-galactosidase or other E. coli proteins (Fig. 2D).

\section{Localization of Scr protein in embryos}

To localize Scr protein during embryogenesis, the method described by Karr and Alberts (1986) and Carroll and Scott (1985) for immunofluorescent staining of formaldehyde/heptane-fixed whole Drosophila embryos was used. This procedure allows staining of embryos at all stages until about $12 \mathrm{hr}$ of development, when cuticle forms around the embryo.

That the patterns observed are due to bona fide $S c r$ protein was demonstrated by the staining of embryos homozygous for a genetically null allele of the $S c r$ locus. Embryos homozygous for the $\mathrm{Scr}^{\mathrm{w} 17}$ presumed null allele (not shown) or hemizygous for the $M s^{1}$ allele (Fig. 5e) 


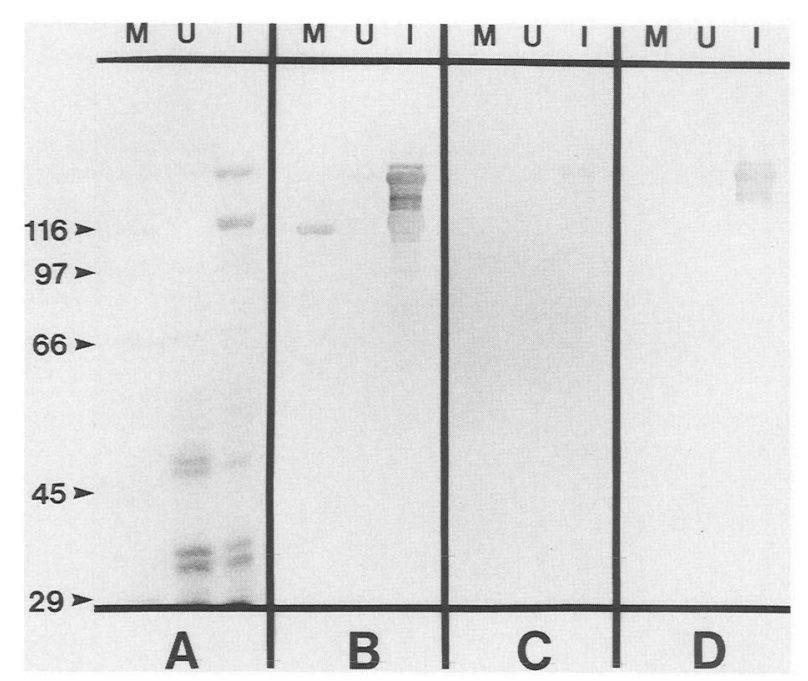

Figure 2. Expression of the $\beta$-galactosidase-Scr fusion protein in $E$. coli and production of specific antibodies to the $S c r$ domain. E. coli cells containing pUR-Scr cDNA plasmid constructions were grown at $37^{\circ} \mathrm{C}$ until log phase growth was reached, then either induced with IPTG for $2 \mathrm{hr}$ at $30^{\circ} \mathrm{C}$ or left uninduced for $2 \mathrm{hr}$ of growth at $30^{\circ} \mathrm{C}$. Cell lysates were electrophoresed on a $7.5 \%$ SDS-polyacrylamide gel. Part of the gel was stained with Coomassie Blue $(A)$, and replicate lanes were transferred to nitrocellulose and immunoblotted with affinitypurified anti- $\beta$-galactosidase antibodies $(B)$, anti-homeodomain antibodies $(C)$, and anti-Scr domain antibodies $(D)$. $(M)$ Marker lanes; $(U)$ uninduced lysates; $(I)$ induced lysates. The molecular weight markers visible in $A$ are $\beta$-galactosidase (116 kD), phosphorylase $\mathrm{b}(97 \mathrm{kD})$, bovine serum albumin $(66 \mathrm{kD})$, ovalbumin (45 kD), and carbonic anhydrase $(29 \mathrm{kD})$.

(Wakimoto and Kaufman 1981) exhibit no detectable antigen staining above background autofluorescence. Therefore, the antibody is only detecting $S \mathrm{Cr}$ antigen or other antigens requiring $S c r$ function for their expression.

About $2.5 \mathrm{hr}$ after egg laying, gastrulation in the Drosophila embryo is initiated with a series of invaginations that eventually establishes the three primary germ layers: the ectoderm, the mesoderm, and the endoderm. At about $3 \mathrm{hr}$ of development, blastoderm cells move toward the ventral midline of the embryo; this ventral ectoderm and its underlying mesoderm form the germ band, which begins to elongate posteriorly. At its fully elongated state, the germ band is wrapped around the posterior end of the embryo so that the most posterior segments lie adjacent and dorsal to the head segment primordia (Turner and Mahowald 1977).

The grooves that first define metamerization appear during the period when the germ band is at full extension. However, these grooves do not, at this stage, define segmental boundaries (Martinez-Arias and Lawrence 1985). Instead, they define what will become the posterior compartment of one segment and the anterior compartment of the next. They have been named "parasegments" (PS). The segmentation gene engrailed (en) is expressed only in cells that will belong to posterior compartments (DiNardo et al. 1985; Kornberg et al. 1985). Therefore, probes for en provide convenient markers for posterior compartmental boundaries. Localization of en transcripts has confirmed the parasegmental identity of the metameres observed in the elongated germ band (Ingham et al. 1985b).

It is toward the end of the germ band elongation stage, just as the parasegmental boundaries become visible and when the number of cells per segment primordium increases from about four to eight, that $S c r$ protein is first detectable by antibody staining. $S c r$ is expressed at this stage in the nuclei of all the ectodermal cells in the PS 2 primordium (posterior maxillary plus anterior labial compartments) (Fig. 3a,b); some staining of the posterior compartment of PS 3 exists in more laterally positioned cells. The positions of the boundaries of $S c r$ expression were confirmed by using a second antibody directed against the en protein in double-label experiments with the Scr antibody (Carroll et al. 1987).

The primordia of the posterior-most structures move to their final posterior position by the process of germ band shortening, reversing the earlier movements of germ band elongation. During germ band shortening, movements of cells through the grooves that demarcate parasegmental boundaries occur, so that after shortening, the grooves define segmental rather than parasegmental units (Ingham et al. 1985b; Martinez-Arias and Lawrence 1985). Therefore, parasegments are no longer defined by morphological boundaries. As germ band shortening begins, additional $S c r$ protein appears in a discrete group of cells in the lateral portions of anterior T1 (Fig. 3c,d, and 5a).

Also during germ band shortening, cells in the lateral parts of the labial segment move ventrally until two paired labial lobes are formed. The cell nuclei within these lobes express $S c r$ protein at higher levels than any other cells at any time during embryonic development (Fig. 3e). After germ band shortening is complete, staining in anterior $\mathrm{Tl}$ becomes more uniform across the entire compartment. In addition to the lateral epidermal cells in anterior T1 already expressing Scr protein, cells in the ventral portion of that compartment begin to express the protein (Fig. 3e,f). However, the staining in the most ventral part of anterior $\mathrm{T} 1$ remains less intense than staining in the lateral regions. Furthermore, the staining in anterior $\mathrm{Tl}$ is never as intense as that in the labial lobes. Cells in part of the posterior compartment of the maxillary segment still contain detectable $S c r$ protein after germ band shortening (arrow in Fig. 3f), as do some lateral cells within the posterior T1 epidermis. Therefore, at the completion of germ band shortening, almost all of the ectoderm nuclei in PS 2 and 3 express Scr protein. Mesodermal staining is difficult to observe at these stages and will not be described here.

At about $9 \mathrm{hr}$ of embryogenesis, the labial lobes fuse. The fused lobes then move interiorly along with the other head segments during the process of head involution (Turner and Mahowald 1979). As head involution proceeds, Scr protein becomes detectable in the posterior portion of the subesophageal ganglion in the central nervous system and in two small, paired clusters of cells within the first thoracic ganglion (Fig. $3 g$, solid arrow). This nervous system expression appears to occur in cells 
Riley et al.

Figure 3. Expression of $S c r$ protein in the ectoderm and nervous system during embryogenesis. In all photos, ventral is toward the bottom and anterior is toward the left. (a) Embryo at elongated-germ-band stage, after cell division has resumed in the ectoderm. A weak $S c r$ signal is detectable in the nuclei of the PS 2 primordium. $(b)$ Higher-magnification view of $a$. $(c)$ An embryo beginning to undergo germ band shortening after segmental boundaries have appeared. The Scr protein is in the nuclei of the posterior compartment of the maxillary segment, as well as the entire labial segment, and is beginning to appear laterally in the anterior compartment of Tl. Therefore, protein is detected in most of PS 2 and 3. $(d)$ Highermagnification view of $c$. The arrow points to the boundary between the maxillary and labial segments. $(e)$ A ventro-lateral view of an embryo after germ band shortening. The labial segment has formed distinct ventral lobes. Scr protein is present at high levels in all cells of the labial lobes. Scr protein is also present at lower levels in anterior $\mathrm{T} 1$ and in the posterior maxillary compartment. $(f)$ Higher magnification of an embryo at a stage similar to $e$. The arrow points to posterior maxillary cells that are expressing the $S c r$ product. $(g)$ Ventrolateral view of an embryo undergoing head involution. The labial lobes have fused anteriorly, and the elongated central nervous system is now detectably expressing $S c r$ protein. Scr protein is visible in the labial ganglion, as well as at two small, paired sites in the first thoracic ganglion (solid arrow). Note persistent but fading ectodermal nuclear staining in anterior $\mathrm{Tl}$ (open arrow). (h) Highermagnification view of an embryo at a stage similar to $g$. $\mathrm{Scr}$ protein is visible in two clusters of cell nuclei (arrow) posterior to $\mathrm{Tl}$ that are probably mesodermal. (These cells are also faintly visible in the embryo shown in $\mathrm{g}$.)

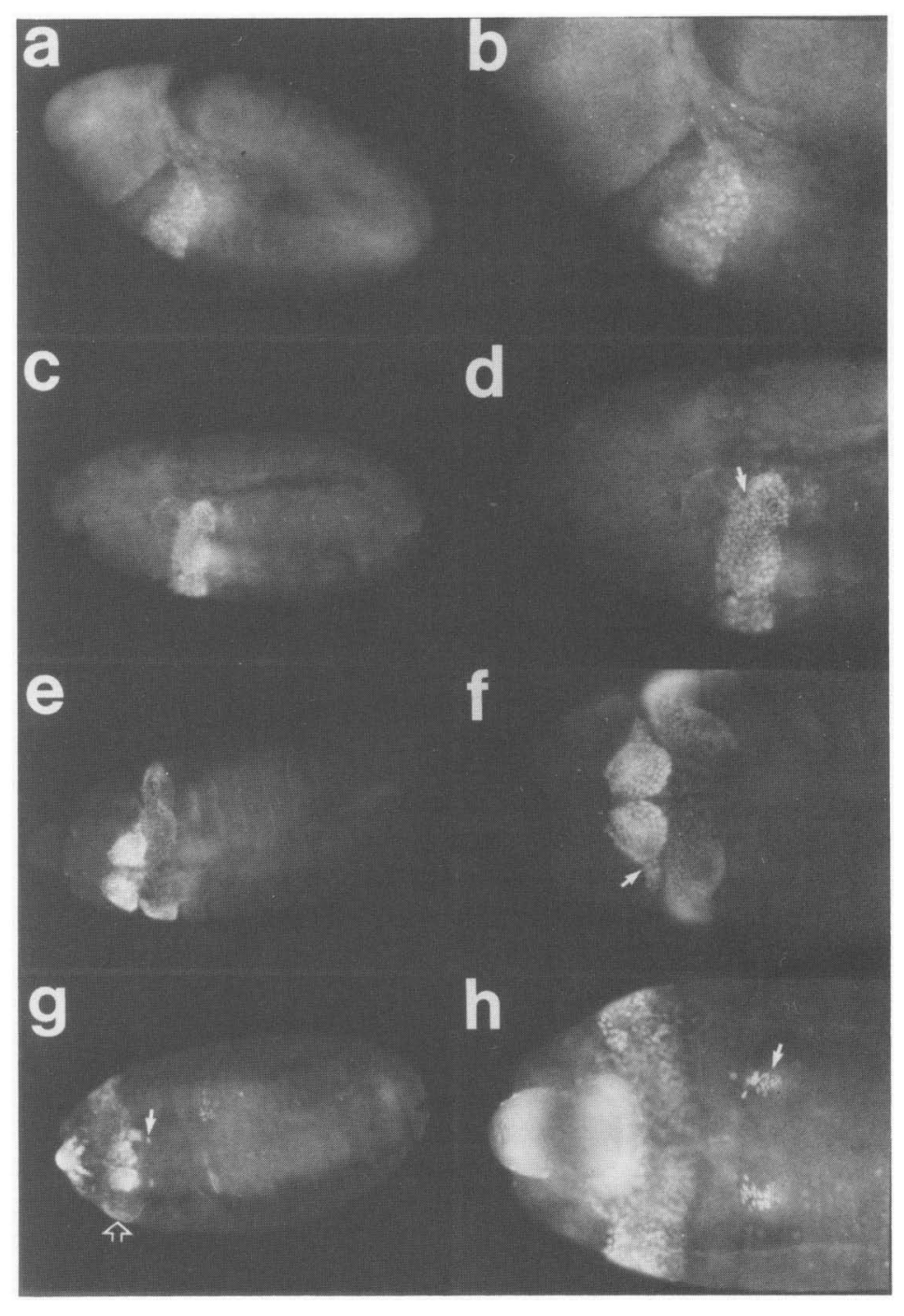

that had not previously expressed $S c r$ at detectable levels. During head involution, $S c r$ expression in the epidermal ectoderm can be seen at a low level in anterior $\mathrm{T} 1$, and the signal gradually fades. Scr protein is also observed in two paired clusters of nuclei posterior to T1 (Fig. 3h, arrow). We are not certain of the identity of these cells at present, but they may be visceral mesoderm cells (P.A. Lawrence, pers. comm.). Scr protein is no longer detectable in whole mounts after about $12 \mathrm{hr}$ due to cuticle formation.

\section{Scr protein expression in segmentation and homeotic mutants}

It has been observed using in situ hybridization that homeotic genes of the ANT-C and BX-C are regulated by at least three distinguishable classes of genes: globally acting homeotic genes (Ingham 1985; Struhl and Akam 1985; Carroll et al. 1986a; Struhl and White 1986; Wedeen et al. 1986), other members of the ANT-C and BX-C homeotic gene complexes (Hafen et al. 1985; Carroll et al. 1986a; Struhl and White 1986; Wirz et al. 1986), and segmentation genes (Ingham and Martinez-
Arias 1986; Ingham et al. 1986; White and Lehmann 1986). The results from molecular analyses are consistent with genetic evidence for the control of homeotic genes (Lewis 1978; Struhl 1981; Raff and Kaufman 1983; Duncan 1986; Bender et al. 1987; Lehmann and Nüsslein-Volhard 1987). To study the regulation of Scr by other genes of each class, we examined its pattern of expression in embryos mutant for several homeotic and segmentation loci.

\section{Control of Scr by segmentation genes}

To regulate segmental differentiation precisely, homeotic genes elaborate on events that occur earlier in embryogenesis under the control of segmentation genes. Thus, homeotic gene expression respects boundaries, such as compartmental or parasegmental boundaries, that are set up by segmentation gene functions. However, in addition to subdividing the embryo into metameres, at least some segmentation genes appear to play a role in differential activation of homeotic genes along the anterior-posterior embryonic axis (refs. above). To study the effect of segmentation genes on $S c r$ expres- 


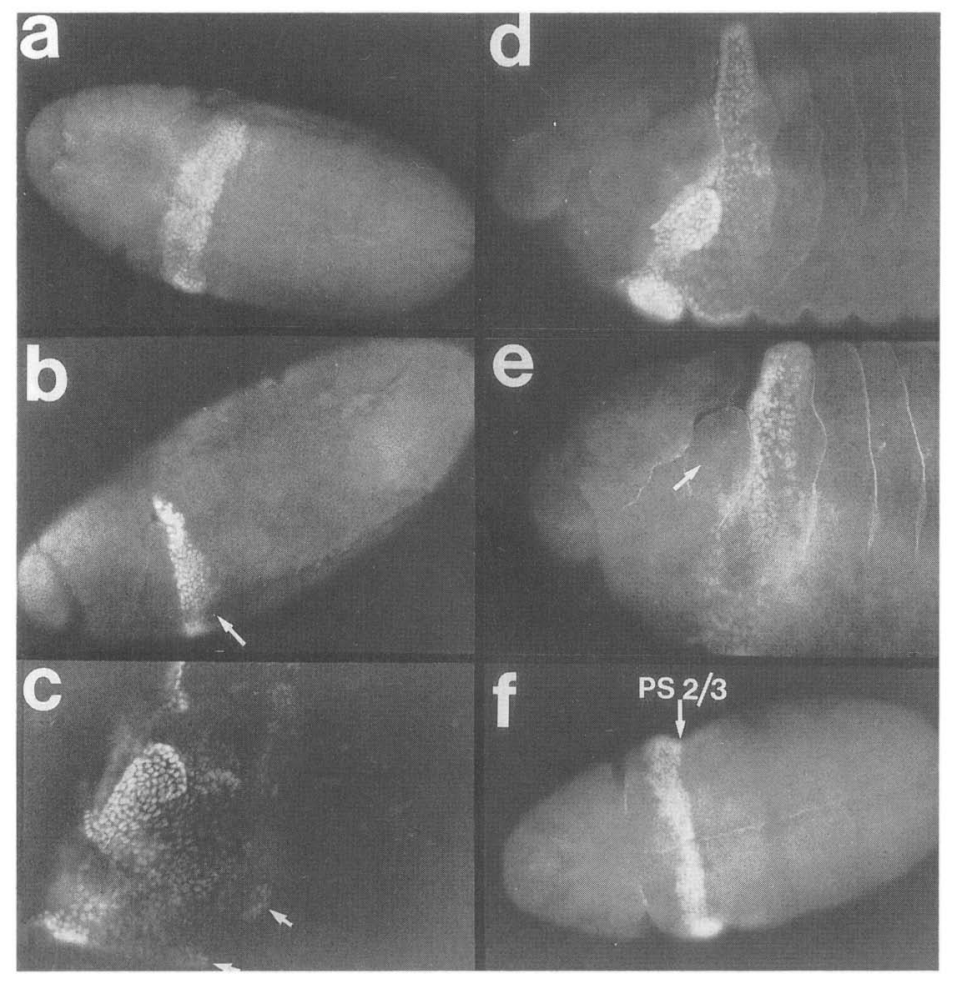

Figure 4. Scr protein expression in embryos mutant for segmentation genes. (a) Ventral view of a wild-type embryo at the elongated-germ-band stage. High-level Scr protein expression is visible in nuclei within PS 2 (posterior maxillary plus anterior labial segments). $(b)$ Ventral view of homozygous $h b^{-}$embryo, $D f(3 R) p^{25}$ $D f\left(3 R \mid p^{25}\right.$, at a stage similar to the embryos shown in $a$. The anterior border of $S c r$ expression at PS 1/PS 2 is apparently normal. Because the band of $S c r$ protein is distinctly narrower than in the wild-type case, some cells within the posterior portion of PS 2 (arrow) do not express $S c r$ protein. Compare this to the wild-type pattern in $a$, where approximately twice as many cells in PS 2 express Scr. PS 3 expression does not occur at any stage in $h b^{-}$embryos. (c) Ventro-lateral view of a homozygous $\mathrm{Kr}^{256}$ embryo at the same magnification and stage as embryos in $d$ and $e$. Scr expression is largely normal except at its most posterior edge, where it extends laterally into PS 4 (arrows). (d) Higher-magnification, ventro-lateral view of the anterior portion of a wild-type embryo after germ band shortening. (e) Ventro-lateral view of anterior portion of a homozygous $g t^{Y A 82}$ embryo at the same magnification and similar stage as embryo shown in $d$. Scr protein expression appears normal in anterior $\mathrm{Tl}$ in terms of both localization and level of expression. However, the labial lobes have not formed, and the cells that would normally form them are not expressing any detectable amounts of $S c r$ protein (arrow). $(f)$ Ventral view of homozygous $f t z^{w 20}$ embryo at similar age to embryo shown in $a$. Due to the lack of proper $f t z$ function, only double-width parasegments are formed. The parasegment $1 / 2$ boundary is missing, whereas the parasegment $2 / 3$ boundary (arrow) appears normal. $S c r$ protein is visible in the posterior portion of the double parasegment spanning the normal parasegment $1 / 2$ region. This $S c r$ expression corresponds to only part of the normal PS 2 expression (see text for discussion).

sion, embryos mutant for each of the four zygotically active gap segmentation loci so far identified - giant $(g t)$, Krüppel (Kr), knirps (kni), and hunchback (hb) - and for one pair-rule locus, fushi tarazu (ftz), were examined.

Mutations in the gap segmentation genes $k n i, h b, K r$, and $g t$ cause deletions of groups of segments. $\mathrm{kni}^{-} \mathrm{em}-$ bryos have deletions in the abdomen: segments $\mathrm{Al}-\mathrm{A} 7$ are lacking (Nüsslein-Volhard and Wieschaus 1980). As expected, given the labial and prothoracic expression of $\mathrm{Scr}, \mathrm{Scr}$ expression is unchanged in $\mathrm{kni}^{-}$embryos (data not shown). The $h b, K r$, and gt genes all affect head or thoracic segments and thus could influence Scr expression.

In strong $h b$ alleles, the labial segment, the three thoracic segments, the entire eighth abdominal segment, and part of the seventh abdominal segment are not formed. However, the blastoderm stage embryo has the usual number of cells and appears to be normal (Bender et al. 1987; Lehmann and Nüsslein-Volhard 1987). In the present study, embryos homozygous for the deficiency $D f\left(3 R \mid p^{25}\right.$, which removes $h b$ and neighboring genes, were analyzed. These embryos showed a band of Scr expression distinctly narrower than that observed in wildtype embryos (Fig. 4b). A hypomorphic $h b$ allele, $h b^{6 N 47}$, had similar effects (data not shown), suggesting that the effect of $D f(3 R) p^{25}$ on $S c r$ is due to loss of $h b$ and not to the loss of neighboring genes within the deletion. $h b$ embryos lack many of the anterior morphological landmarks (Bender et al. 1987; Lehmann and Nüsslein-Vol- hard 1987) therefore, it is difficult to define the position of $\mathrm{Scr}$ expression precisely. The band of $\mathrm{Scr}$ protein is definitely narrower than wild-type PS 2 expression, but its position along the length of the embryo is close to the position of PS 2 in the wild type (compare to Fig. 4a). Because the anterior border of the Scr protein appears to be in the correct position and has a well-defined boundary, whereas the posterior boundary is uneven (arrow in Fig. 4b), Scr expression is likely to be missing from cells that would normally form posterior PS 2 and all of PS 3 at this stage. There is a maternal contribution of $h b$ product to the embryo (Lehmann and NüssleinVolhard 1987), so the effects of $h b$ on $S c r$ could be more pronounced than the present experiments reveal.

Like $h b^{-}$embryos, $g t^{-}$embryos have a "double gap" phenotype; two sets of segments fail to form, one set comprised of the fifth through seventh abdominal segments, and one set comprised of the head and anterior thoracic segments (Petschek et al. 1987). Embryos hemizygous or homozygous for the $g t^{Y A 82}$ allele have an apparently wild-type thorax and anterior abdomen, but have abnormal (or missing) head structures such as the mouth hooks and the hypophyseal and labial sense organs (Gergen and Wieschaus 1986). Embryos homozygous for the $g t^{Y A 82}$ allele have apparently normal $S c r$ expression in anterior T1 (posterior PS 3), but completely lack $S c r$ protein in any regions anterior to that compartment at any stage (Fig. 4e, compare to Fig. 4d). Observation of the head region of these embryos after 
they have completed germ band shortening reveals that they lack labial lobes entirely, and none of the cells that would normally form the labium express $\mathrm{Scr} . \mathrm{gt}^{-} \mathrm{em}-$ bryos at the germ band elongation stage never express Scr in PS 2; PS 3 expression begins without any prior PS 2 expression.

$\mathrm{Kr}^{-}$embryos lack all of the thoracic segments and several anterior abdominal segments; in their place a mirror-image duplication of posterior abdominal segments is observed (Wieschaus et al. 1984). In embryos homozygous for the $\mathrm{Kr}^{256}$ allele, $\mathrm{Scr}$ expression in PS 2 is normal and is only slightly altered in PS 3 (Fig. 4c). Near the boundary between what would normally be PS 3 and 4, the pattern of $S c r$ expression is uneven and weak and extends into the region that would normally be occupied by PS 4 (arrows in Fig. 4c). This suggests that $K r$ function probably extends anteriorly at least to the PS $3 / 4$ boundary, which is consistent with genetic (Wieschaus et al. 1984) and molecular (Knipple et al. 1985) data.

$\mathrm{ftz}$ is a member of the pair-rule class of segmentation genes, and is located within the ANT-C (Wakimoto and Kaufman 1981). Early in wild-type embryogenesis, at the cellular blastoderm stage, $f t z$ protein is expressed in six approximately four-cell-wide transverse stripes and one posterior five-cell-wide transverse stripe (Hafen et al. 1984; Carroll and Scott 1985). From the relationship of the most anterior stripe to the cephalic furrow and from recent double-label experiments with an en antibody (S.B. Carroll et al., in prep.), the stripes of $f t z$ protein expression in wild-type embryos appear to correspond to alternate, even-numbered parasegments (Martinez-Arias and Lawrence 1985). In $\mathrm{ftz}^{-}$embryos, only half as many grooves are observed. Because the grooves demarcating metameric units at germ band elongation correspond to parasegmental boundaries (Ingham et al. 1985b), each double-wide unit observed in $f z^{-}$embryos at this stage can be regarded as a "double parasegment." Thus, in $f t z^{-}$ embryos, PS 1 and 2 are fused as are PS 3 and 4, 5 and 6, and so on, due to the lack of $f t z$ function in parasegments $2,4,6$, etc.

Detectable $S c r$ protein expression in wild-type embryos begins after the germ band is fully elongated and after $\mathrm{ftz}$ protein expression has ceased in the epidermal ectoderm. Embryos homozygous for the null $f t z^{w 20}$ allele, which lacks detectable $f t z$ protein (Carroll and Scott 1985), have $S c r$ protein in the posterior region of the double parasegment that corresponds to wild-type PS 1 and 2 (Fig. 4f). Since the labial lobes begin to form dorso-laterally at this stage and cause the embryos to bulge along the sides, it is simplest to use the ventral midline as a reference point for comparison with the wild type (Fig. 4a). Fewer cells express $S c r$ in $f t z^{-}$embryos than in wild-type embryos. Scr protein appears to be missing from most of the anterior cells of what would in a wild-type embryo be PS 2 . When germ band shortening begins, the appropriate time for $S c r$ expression in wild-type PS 3 to appear, Scr protein is detectable in a $\mathrm{ftz}^{-}$embryo in the anterior of the next double parasegment (PS 3/4). After germ band shortening is completed, the PS 3/4 expression corresponds to about the anterior one-half of the cells in PS 3/4 (not shown). Therefore, it is likely that PS 3 expression is unchanged in $\mathrm{ftz}^{-}$embryos.

\section{Control of Scr by other homeotic genes}

$P c$ is an example of a homeotic gene that influences the development of many segments during embryogenesis. Embryos lacking normal Pc gene function show multiple homeotic transformations; these are thought to be due to the inappropriate activation of ANT-C and BX-C genes in cells where they should be off (Lewis 1978; Duncan and Lewis 1982; Sato and Denell 1985; Capdevila et al. 1986). We examined embryos homozygous for the strong $P C^{R I}$ allele (Kennison and Russell 1987) with the anti-Scr antibody. $\mathrm{PC}^{-}$embryos express several homeotic gene products ectopically (Beachy et al. 1984; Cabrera et al. 1985; Carroll et al. 1986a; Wedeen et al. 1986), and, correspondingly, Scr protein is expressed in many areas of the embryo where it would normally not be activated (Fig. 5 b). In addition to the wild-type pattern of $S c r$ expression in PS 2 and 3, in $P c^{R I}$ homozygotes $S c r$ protein is detectable both anterior to PS 2 in the putative maxillary lobes, posterior to PS 3 in the remaining thoracic segments, and throughout the entire abdomen. Only restricted patches of cell nuclei in the maxillary lobes have detectable $S c r$ protein (solid arrow in Fig. 5b; compare to Fig. $5 a$, but note that $5 a$ and $5 b$ are viewed at different angles). The strong labial expression of $S c r$ is present in both $a$ and $b$ of Figure 5. In the thoracic and abdominal segments, only cells in the lateral regions of each segment appear to make Scr protein (e.g., open arrow in Fig. 5b). Cells in both the anterior and posterior compartments express the protein; the level of expression is reduced in more posterior segments (Fig. $5 \mathrm{~b}$ ). Thus, even in $P C^{R 1}$ homozygotes not all cells contain $S c r$ protein; other influences besides the action of the $P c$ gene still restrict the expression pattern. These other influences could be other genes or the maternal contribution of $P c$ products (Denell 1982).

In addition to regulation by loci such as $P c$, it is possible that $S c r$, like Antp and $U b x$, is regulated by other homeotic genes in the ANT-C and BX-C. To test this possibility, embryos lacking Antp, $U b x$, or $D f d$ function were examined. In embryos homozygous for the null Ant $p^{w 10}$ allele, which makes no detectable Antp protein (Carroll et al. 1986a), there is a subtle change: Scr protein is found in the posterior compartment of $\mathrm{T} 1$ and in the anterior compartment of T2 (Fig. 5d), whereas in wild-type embryos, $S c r$ expression occurs only in anterior T1 and further anterior (Fig. 5c). Antp is expressed in posterior $\mathrm{T} 1$ (and anterior T2) in wild-type embryos. The nuclei containing $S c r$ protein in Antp ${ }^{w 10}$ homozygotes are observed only one cell posterior to the T1/T2 boundary in the most lateral regions, and only three to four cells posterior to the same boundary in the ventral region of T2. No $S c r$ protein is detectable in any ectodermal cells posterior to these, and no ectopic staining is visible anterior to the normal pattern of PS 2 expression. The levels of Scr protein in homozygous $A n t^{\text {w10 }}$ embryos appear to be equivalent to the wild-type levels, and the $S c r$ protein in ectopic positions in posterior $\mathrm{Tl}$ and ante- 


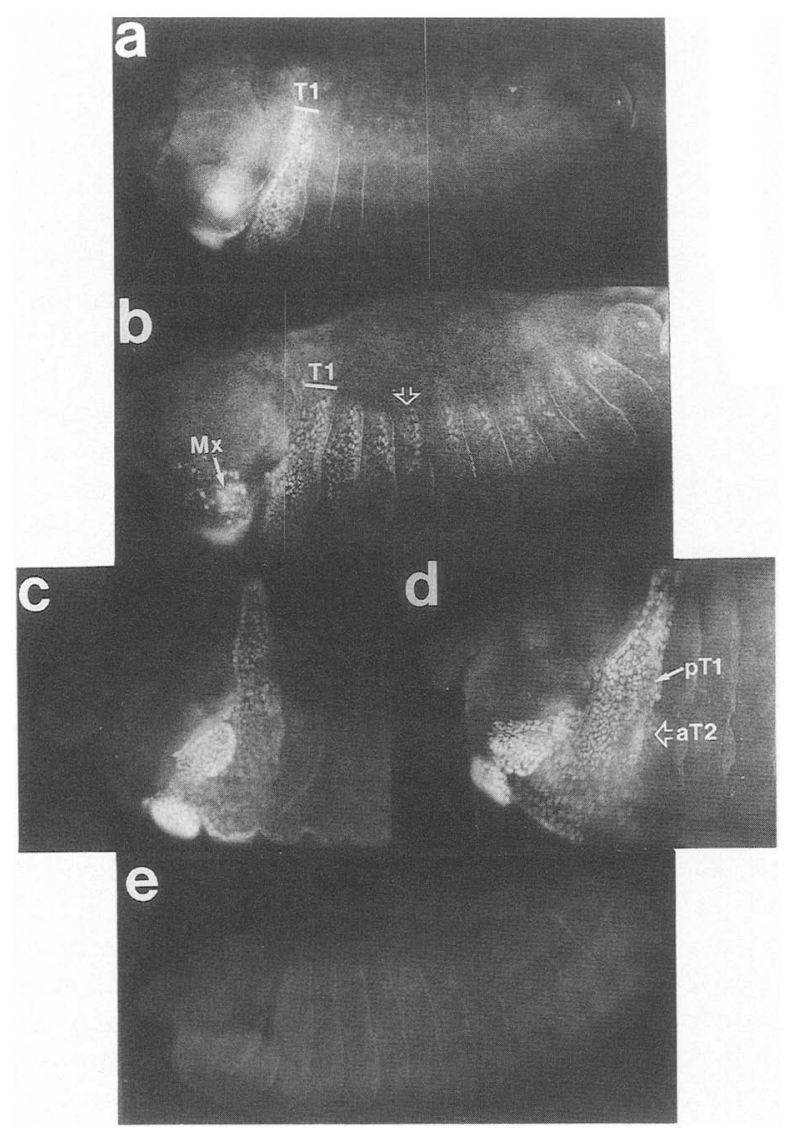

Figure 5. Expression of $S c r$ protein in the Polycomb, Antennapedia, and Multiple sex combs mutant embryos. (a) Lateral view of $S c r$ protein in a wild-type embryo after germ band shortening is complete. In this view, the labial lobes (which are expressing $S c r$ protein at high levels) are not readily visible since the ventral midline of the embryo is facing directly downward and the lobes are out of the plane of focus. This embryo is very similar in stage of development and pattern of $\mathrm{Scr}$ expression to the embryo shown in Fig. 3e. (b) Lateral view of $S c r$ protein expression in a homozygous $P C^{R 1}$ embryo similar in stage to the embryo shown in $a$. The labial lobes are expressing $S c r$ in the wild-type pattern but are barely visible in this view. In addition to the wild-type distribution of $S c r$ protein in the labial and T1 segments, there is ectopic $S c r$ protein expression in some of the nuclei within the maxillary lobes (solid arrow) and in many of the cell nuclei in lateral positions in segments extending posteriorly from posterior $\mathrm{T} 1$ through the abdominal segments. For example, note antigen in the lateral region of the first abdominal segment (open arrow). (c) Ventro-lateral view of $\mathrm{Scr}$ protein expression in the anterior portion of a wild-type embryo after germ band shortening is complete. $(d)$ Ventro-lateral view of the anterior portion of a homozygous Ant ${ }^{\mathrm{w} 10} \mathrm{em}$ bryo. In addition to the wild-type pattern of PS2 and 3 expression, embryos lacking Antp function show expression of $\mathrm{Scr}$ protein ectopically in the nuclei of posterior T1 (solid arrow) and in some nuclei in the anterior compartment of T2 lopen arrow). $S c r$ protein expression in anterior $\mathrm{T} 2$ is not observed in all of the nuclei within the compartment; rather, it extends only one to three cells posterior to the T1/T2 boundary. (e) Lateral view of $M s c^{1} / D f(3 R) S c r$ embryo after germ band shortening. $S c r$ protein expression is not detectable above background autofluorescence in $M s c$ embryos. rior T2 expression appears to persist during germ band shortening at a level comparable to wild-type anterior $\mathrm{T} 1$ expression. $S c r$ is not expressed ectopically in all the places where Antp is normally expressed (Carroll et al. 1986a, Wirz et al. 1986), indicating that other genes continue to restrict $S c r$ expression (or fail to activate it) in the thorax.

The $D f d$ gene is active in head segments anterior to the regions of Scr activity (Kaufman 1983; Chadwick and McGinnis 1987; Martinez-Arias et al. 1987; Regulski et al. 1987). Of several hundred embryos homozygous for the strong $D f d$ allele examined, none had a detectably altered pattern of $S c r$ expression (data not shown). Embryos lacking all of the BX-C (embryos homozygous for $D f(3 R) P 9$; Lewis 1978) also appeared to have a normal Scr pattern. The mutant genotype of the $D f(3 R) P 9$ homozygous embryos was confirmed in double-label experiments (not shown) performed with a mouse monoclonal anti-Ubx antibody (White and Wilcox 1985). Thus, any change in Scr function in BX-C- embryos is either too subtle to be detected or affects an aspect of $S c r$ expression other than protein distribution (see Discussion).

The Multiple sex combs $\left(M s^{1}\right.$ ) allele of Scr (Tokunaga 1972 ) is characterized by two different phenotypes: the $S c r$ loss of function (T1 $\rightarrow \mathrm{T} 2$ ) phenotype and the appearance of sex combs on the $\mathrm{T} 2$ and $\mathrm{T} 3$, indicating $\mathrm{T} 2+\mathrm{T} 3 \rightarrow \mathrm{T} 1$ transformations. The $\mathrm{T} 2+\mathrm{T} 3 \rightarrow \mathrm{T} 1$ effect is dominant, possibly representing ectopic activation of $S c r$ at abnormal times or in abnormal places. Therefore, in $M s c^{1}$ homozygotes one might expect a loss of $S c r$ function in T1, plus novel expression in T2 and T3. Embryos heterozygous for the $M s c^{1}$ allele and a deficiency for a chromosomal region that includes the $S c r$. gene, Df(3R)Scr, were examined. Such embryos do not have detectable $S c r$ protein expression in any cells during any stages of embryogenesis until cuticle formation (Fig. 5e). This observation further demonstrates that the antibody is recognizing authentic $S c r$ antigen and suggests that ectopic expression of $\mathrm{Scr}$ in T2 and T3, if it occurs, may happen only at later stages of development or may require a wild-type $S c r$ allele in trans. However, no ectopic expression was observed in the $M s c^{1 /}+$ heterozygous embryos.

\section{Discussion}

\section{The patterns of Scr protein during Drosophila embryogenesis}

The spatial pattern of $S c r$ protein expression is largely consistent with the parts of the embryo that are affected by $S c r$ mutations and with the pattern of RNA expression revealed by in situ hybridization. Martinez-Arias et al. (1987) report RNA transcripts hybridizing to probes from both $S c r$ exons localized primarily in a three- to four-cell-wide band at the time of cellular blastoderm. They believe this band to represent the primordial cells of PS 2, as revealed by their mentioned (but unpubl.) double-label experiments with an en probe. Recent double-label experiments with en and Scr antibodies 
confirm the parasegmental distributions of the Scr protein (Carroll et al. 1987). Scr transcripts containing the $3^{\prime}$ exon are detectable about $2 \mathrm{hr}$ before $S c r$ protein is detected. Similar lags between RNA and protein detection have been noted with the $U b x$ and Antp homeotic genes (Carroll et al. 1986a). In the case of Scr, the lag cannot be due merely to the length of the transcription unit, since the lag occurs after the 3 ' part of the transcript is detected. The delay between the time of transcript detection and protein detection may be a measure of the insensitivity of antibodies to small amounts of protein, or it may indicate that posttranscriptional controls are operating.

Scr transcripts are observed at the highest level in PS 2. In addition, at the cellular blastoderm stage, in situ hybridization with the $5^{\prime}$ Scr exon (but not the $3^{\prime}$ exon) reveals a lower level of RNA transcripts in parasegments 4, 6, 8, 10, 12, and 14 (Ingham and Martinez-Arias 1986; Martinez-Arias et al. 1987). Protein is detected only in PS 2 and never in more posterior even-numbered parasegments. The transient appearance of $S c r$ transcripts in PS 4, 6, 8, 10, 12, and 14 may lead to only a low level of protein that is not detected, or the Scr transcripts in the more posterior regions may not be translated, or the transcripts may not contain all of the $S c r$ protein-coding sequence. The activation of $S c r$ in the more posterior parasegments, in the same pattern as the $f t z$ gene products, could be due to an effect on the $S c r$ promoter of the closely linked $f t z$ regulatory sequences.

The sites of $S c r$ protein expression also correlate well with the sites of RNA expression in the central nervous system. The accumulation of Scr RNA in PS 2 of the central nervous system at the time of germ band shortening (Harding et al. 1985; Martinez-Arias et al. 1987) is in agreement with the observation of $\mathrm{Scr}$ protein in the same region after head involution. Kuroiwa et al. (1986) report that in addition to transcripts found in the PS 2 region, there is also Scr RNA in the anterior portion of the prothoracic ganglion. This RNA probably gives rise to the protein seen in clusters of nuclei within the prothoracic ganglion (Fig. $3 \mathrm{~g}$ ). There are regions of the central nervous system where RNA, but not protein, is detected. Kuroiwa et al. (1985) note low but significant levels of Scr RNA throughout the entire central nervous system, both anterior and posterior to the high-level transcription in PS 2 and 3. Similarly, Martinez-Arias et al. (1987) report Scr RNA from both exons at very low levels in regions posterior to the areas of high-level transcription, in the ganglia of parasegments 6 through 12 . We do not detect Scr protein expression in any part of the central nervous system anterior to the subesophageal ganglion or posterior to the prothoracic ganglion. The low level of RNA in PS 6-12 of the nervous system, if translated with the same efficiency as the high-level RNA in the anterior, would probably give rise to too low a level of protein to be above the background level.

The Scr phenotype correlates with the major sites of Scr protein accumulation. The phenotype of homozygous $\mathrm{Scr}^{-}$embryos has been described as a transformation of the labial segment into a maxillary segment and of the prothoracic segment into a mesothoracic seg- ment (Wakimoto and Kaufman 1981; Sato et al. 1985). Similar transformations are observed in adults (Kaufman 1980; Lewis et al. 1980; Struhl 1982). In the embryo we observe $S c r$ protein in PS 2 and 3, i.e., the posterior maxillary segment, all of the labial segment, and the anterior prothoracic segment. Because the morphological markings of the segments are limited, particularly in the posterior compartments, we believe that there is good correspondence between the locations of $S c r$ protein and the parts of the embryo that are altered in $S_{c r}{ }^{-}$homozygotes. The loss of $\mathrm{Scr}^{+}$activity in the posterior maxillary segment might well be difficult to observe as a phenotype, and the lack of the requirement for $\mathrm{Scr}^{+}$in posterior Tl would also be easily missed as there are minimal distinguishing morphological features of posterior $\mathrm{T} 1$. Some effect of the absence of $S c r$ function has been detected in the T2 through A7 segments in embryos that also lack the BX-C (Sato et al. 1985); these posterior Scr functions might be related to the transient $S c r$ transcripts in PS 4, 6, 8, 10, 12, and 14.

The $M s^{1}$ allele of $S c r$, a chromosome inversion (Fig. 1a), causes $\mathrm{T} 1 \rightarrow \mathrm{T} 2$ and $\mathrm{T} 2+\mathrm{T} 3 \rightarrow \mathrm{T} 1$ transformations in adults. The former transformation, which is also observed in hemizygous embryos, is in agreement with the absence of $S c r$ protein from $M s^{1}$ hemizygous embryos. The $\mathrm{T} 2+\mathrm{T} 3 \rightarrow \mathrm{T} 1$ dominant transformation suggests that the $M s c^{1}$ allele causes Scr activity in T2 and T3 where $S c r$ is normally off. A disruption of the T2 denticle belt in $M s c^{1} / D f|3 R| S c r$ (i.e., hemizygous) embryos indicates an effect of $M \mathrm{Mc}^{1}$ (but not loss-of-function $S \mathrm{Cr}$ alleles) on T2 (Wakimoto and Kaufman 1981). However, no $S c r$ protein is seen in T2 or T3 in $M s c^{1} / D f$ embryos. One possible explanation is that the amount of ectopic protein is too low to be detected; another is that the protein is made only during cuticle formation, at a time when the methods used here cannot detect it. A more interesting possibility is that the $\mathrm{T} 2+\mathrm{T} 3 \rightarrow \mathrm{T} 1$ transformation does not require ectopic $S c r$ protein expression at all and might instead be due to altered expression of Antp due to the nearby Msc chromosome inversion. Certain alleles of Antp are also capable of causing the T2 and $\mathrm{T} 3 \rightarrow \mathrm{T} 1$ transformation (Hazelrigg and Kaufman 1983). This hypothesis has not yet been tested.

\section{The pattern of Scr expression in segmentation and homeotic mutants}

Because segmentation genes are known to act prior to homeotic genes in embryogenesis, a picture of hierarchical regulatory interactions between the different classes of developmentally important genes has emerged. The gap loci are thought to act to define broad regions in the early embryo. The pair-rule and segment polarity loci more precisely define cell identities. Acting somewhat later, homeotic genes direct unique segmental specification.

That segmentation genes are involved with the initiation of correct homeotic gene expression is supported by recent genetic and molecular studies of homeotic gene function in embryos mutant for segmentation genes. An example is provided by the effect of the gap locus $h b$ on 
the homeotic BX-C gene $U b x$. $U b x$ protein expression extends much farther anteriorly in embryos with strong $h b$ mutations than in wild-type embryos (White and Lehmann 1986). Therefore, $h b^{+}$normally represses $U b x$ activity in the anterior regions. Correspondingly, transformations of head segments into thoracic or abdominal segments are observed in embryos carrying certain $h b$ alleles (Lehmann and Nüsslein-Volhard 1987). $h b$ also appears to be able to affect $U b x$ function in the thorax, in that the Regulator of postbithorax allele of $h b$ alters thoracic determination (Bender et al. 1987). To see whether segmentation genes similarly regulate $S c r$, we examined the pattern of $S c r$ expression in embryos mutant for any of several different segmentation genes. Since $S c r$ is expressed primarily in the labium and prothorax, we expected that the segmentation genes that affect those regions would also affect the pattern of $\mathrm{Scr}$ expression. $g t, h b$, and $K r$ mutant embryos all have thoracic and/or labial defects and each was found to affect $S c r$ expression. Embryos lacking gt function do not express $S c r$ in the labial and posterior maxillary regions, and, in $h b^{-}$embryos, the band of Scr expression observed in wild-type embryos prior to germ band shortening is significantly narrowed. The latter effect is probably due to a failure of cells in the posterior part of what would normally be PS 2 to express Scr. The loss of $K r$ function leads to minor defects in the Scr pattern in PS 3 and to some ectopic expression in cells that would normally be within PS 4 . Since the $K r$ and $h b$ genes appear to be mutually negative regulators, i.e., each will expand its region of expression if the other is removed (Jäckle et al. 1986), effects on Scr could be due to the absence of one gene or to the expanded expression of the other or both.

$f t z$, a pair-rule segmentation gene, has been shown to have an effect on the expression of the homeotic genes Antp, Ubx, and Scr at the RNA level. Normally, Antp (Martinez-Arias 1986) and Ubx (Akam 1985) are expressed at a high level in PS 4 and 6, respectively. In wild-type embryos, $U b x$ RNA is also transiently accumulated in PS 8, 10, and 12 in a ftz-like pattern (Akam 1985|, whereas Scr RNA is detected for a brief time in a seven-striped pattern very similar to the $f t z$ pattern (Ingham and Martinez-Arias 1986; Martinez-Arias et al. 1987). These characteristics of $U b x, A n t p$, and Scr expression have been described as "pair-rule modulation" (Akam 1985) and have been shown to be dependent on $f t z$ function (Ingham and Martinez-Arias 1986). In $f t z^{-}$ embryos, transcription of the three homeotic genes is reduced or eliminated in the even-numbered parasegments at the cellular blastoderm stage, i.e., in the places where $f t z$ is normally active. Thus, $f t z$ function appears to enhance transcription of the homeotic genes in even-numbered parasegments. The early expression of Scr RNA in PS 2, 4, 6, 8, 10, 12, and 14 is absent in embryos homozygous for a null allele of $f t z$ (Ingham and MartinezArias 1986). We examined embryos for the same $f t z$ null allele $\left(f t z^{W 2 O}\right)$ for evidence of $S c r$ protein expression. Surprisingly, high-level $S c r$ protein expression was observed in part of PS 2 at the normal stage of development (full germ band extension stage) (Fig. 4f). However, the "PS 2"
Scr protein pattern in $\mathrm{ftz}^{-}$embryos is narrower than in wild type. A possible explanation for this observation involves the precise registration of $f t z$ stripes relative to the parasegmental boundaries. After gastrulation, $f t z$ protein expression in wild-type embryos is reduced to stripes that are narrower than the initial stripes: three nuclei instead of four in the six most anterior stripes that express $f t z$ (Carroll and Scott 1985). This may be important with respect to the activation of $S c r$ since the cells that lose $\mathrm{ftz}$ protein as gastrulation begins probably correspond to the most posterior cells of each stripe (Carroll et al. 1987). Thus, the most posterior cells in PS 2 (cells in the anterior labial primordium) may normally stop expressing $f t z$ before $f t z$ can exert a positive effect on Scr. A different gene may act positively on Scr in the most posterior cells of PS 2 and their descendants. Thus, the cells expressing $S \mathrm{cr}$ in the "PS 2 " position of $\mathrm{ftz}^{-}$ embryos may be those cells in which $S c r$ expression is positively regulated not by $\mathrm{ftz}$ but by another gene.

The pattern of $f t z$ expression, like that of $S c r$, is regulated by gap genes (Carroll and Scott 1986), and since $f t z$ has been implicated as an important positive regulator of Scr (Ingham and Martinez-Arias 1986), the gap genes may act upon $S c r$ through $f t z$. In that case the novel $S c r$ pattern in gap mutants might be expected to reflect the novel $f t z$ pattern. Normally $f t z$ protein is found in seven stripes in the even-numbered parasegments $2,4,6,8,10$, 12 , and 14. In embryos homozygous for the $h b$ deficiency $D f\left(3 R \mid p^{25}\right.$, $f t z$ is expressed in a broad solid block in the region of the embryo where the most anterior three stripes would normally be. Expression of $\mathrm{Scr}$ in $\mathrm{hb}^{-}$embryos is eliminated from the cells that would normally comprise PS 3 and reduced in PS 2. Therefore, the increased region of $f t z$ expression is not paralleled by an increase in the region of $S c r$ expression. In the case of $g t^{\mathrm{YA} 82}$ homozygous embryos, the two most anterior $\mathrm{ftz}$ stripes are somewhat wider than normal, whereas Scr expression is eliminated from the cells in the positions of PS 2 and anterior PS 3. Again $\mathrm{ftz}$ and Scr expression seem to be poorly correlated. In $\mathrm{Kr}^{256}$ homozygous embryos, $\mathrm{Scr}$ expression is extended into some of the cells that would normally form PS 4 . $f t z$ expression in embryos homozygous for a different strong allele, $K r^{1}$, is seen in three stripes in the anterior replacing the normal five most anterior stripes. The most anterior stripe may be in position to activate PS $2 \mathrm{Scr}$ expression, but it is difficult to gauge the relationship of the other abnormal $\mathrm{ftz}$ stripes to the altered pattern of $\mathrm{Scr}$ expression. In general, the experiments with the gap mutants suggest that the effects of the gap genes on Scr are mediated not only by $f t z$ but also in other ways. There could be direct interactions of the gap genes with $S c r$, or segmentation genes in addition to $\mathrm{ft} z$ could act as intermediaries.

$S c r$ is also regulated by other homeotic genes. A general paradigm for genetic regulation within the ANT-C and BX-C has emerged: A given homeotic gene tends to have its posterior boundary of high level expression defined by the negative influence of the next most posteriorly acting homeotic gene. For example, in $\mathrm{Ubx}^{-}$embryos, high-level Antp expression extends past its normal posterior border at the anterior-posterior $\mathrm{T} 3$ 
boundary into the first abdominal segment, a region normally under the genetic control of $U b x$ (Hafen et al. 1984; Carroll et al. 1986a). $U b x$, in turn, is negatively regulated in the posterior abdomen by the $a b d A$ and $A b d B$ genes (Struhl and White 1985). Genetic data suggest that Antp and $S c r$ may interact in controlling at least adult structures (Hazelrigg and Kaufman 1983; Kaufman and Abbott 1984), and the position of Antp expression just posterior to Scr (Levine et al. 1983; Carroll et al. 1986a; Martinez-Arias 1986; Wirz et al. 1986) also suggests possible interactions. We observed some ectopic Scr expression in posterior $\mathrm{T} 1$ and anterior $\mathrm{T} 2$ (parts of PS 4) in Antp- embryos. This is not as striking an effect as might be expected. One might predict that Scr expression would extend posteriorly into all of the region under Antp control in embryos lacking Antp function. Antp is expressed at high levels in PS 4 and 5 (Levine et al. 1983; Martinez-Arias 1986; Carroll et al. 1986a; Wirz et al. 1986). Thus, a gene other than Antp may prevent $S c r$ expression in PS 5 and part of PS 4, or Scr may lack an essential activator in those regions.

The temporal changes in Scr expression, particularly the delayed activation of $S c r$ in PS 3, raise the question of what genes might control the changes. The changes occur after the time when homeotic protein products first become detectable, as the germ band is shortening. It is therefore possible that some of the changes in the $S c r$ pattern are due to regulatory interactions with other homeotic genes. Antp protein is found transiently and at a low level in PS 3 in the extended-germ-band stage embryo; as the germ band shortens, Scr expands in PS 3 whereas Antp retreats from it. This suggests that $S c r$ comes on in PS 3 through an unknown mechanism and turns off Antp in PS 3, or that the turning off of Antp by an unknown regulator permits $S c r$ to turn on in PS 3, or that $S r c$ and Antp are both controlled by a third gene, but in opposite ways. No change in the Antp protein pattern was observed in $\mathrm{Scr}^{-}$embryos /Carroll et al. 1986a), which supports the latter model. In addition, we report here (Fig. 5d) that the absence of Antp function leads to ectopic Scr expression in PS 4, a parasegment where Antp protein is normally found at high levels, indicating that Antp is capable of negatively regulating $S c r$ in some cells. However, the lack of Antp function does not lead to distinctly premature or higher-level $S c r$ expression in PS 3. Therefore, we feel that Antp is unlikely to be the most important regulator of Scr in PS 3, though it may have some direct effects.

Curiously, the vast majority of cells in PS 3 of the central nervous system do not express any known homeotic gene at high levels. High-level Antp expression in the nerve cord is located in PS 4 and more posterior regions, though there is a low level of Antp protein in PS 3. Scr expression is restricted to PS 2 and eight nuclei in PS 3. Perhaps another gene is expressed uniquely in PS 3 of the central nervous system and acts coordinately with Antp to regulate $S c r$, or perhaps PS 3 is a "ground state" (as originally suggested by Lewis [1978] for T2) upon which other homeotic genes act to specify other identities. The ground state could be the pattern that develops with input from the segmentation genes only.
We also examined the pattern of $S c r$ protein expression in embryos lacking $D f d$ and $U b x$ function to see if these other homeotic genes regulate $S c r$. It seemed possible that $S c r$ has its anterior limits of expression defined by the next most anteriorly acting homeotic gene, $D f d$, since the phenotype of $\mathrm{Scr}^{-}$embryos consists of an anteriorly as well as a posteriorly directed transformation. A role for $U b x$ in the regulation of $S c r$ has been suggested by the work of Struhl (1982).

It seems likely that neither $D f d$ nor $U b x$ regulates the spatial pattern of $S c r$ expression in embryos. In $\mathrm{Ubx}^{-}$ embryos, a transformation of PS 5 and 6 to PS 4 is observed (Lewis 1981; Morata and Kerridge 1981; Hayes et al. 1984; Struhl 1984). Because Scr protein is not normally made in PS 4, there is not a strong prediction that ectopic $S c r$ protein should be present in $U b x^{-}$embryos. However, clones of $\mathrm{Ubx}^{-}$cells in the posterior second and third legs are transformed into posterior first legs if the clones are induced no later than blastoderm (Morata and Kerridge 1981). Struhl (1982) has shown, by analysis of $\mathrm{Ubx}^{-}$clones and $\mathrm{Ubx}^{-} \mathrm{Scr}^{-}$clones induced at different times, that $\mathrm{Ubx}^{+}$acts early in embryogenesis to prevent $\mathrm{Scr}^{+}$function in the posterior parts of $\mathrm{T} 2$ and T3. If $U b^{-}$clones are induced later than blastoderm, $\mathrm{Ubx}^{+}$has apparently acted already upon $\mathrm{Scr}$ and the absence of $U b x$ function no longer allows $\mathrm{Scr}^{+}$to transform posterior $\mathrm{T} 2$ and $\mathrm{T} 3$ to $\mathrm{T} 1$. The absence of $U b \mathrm{x}^{+}$ function at all stages (as in $U b x^{-}$embryos) might therefore be expected to lead to $S c r$ protein expression in posterior T2 and T3. However, no ectopic Scr protein is seen in $\mathrm{T} 2$ or $\mathrm{T} 3$ in $\mathrm{Ubx}^{-}$embryos. It is possible, however, that small amounts of ectopic expression could escape detection with antibody.

To reconcile the lack of $S c r$ protein in T2 and T3 in $\mathrm{Ubx}^{-}$embryos with Struhl's (1982) evidence for blastoderm stage regulation of $S c r$ by $U b x$, we propose that $U b x$ does indeed negatively control $S c r$ in $T 2$ and $T 3$, but other factors that regulate $S c r$ prevent its immediate ectopic expression in $U b x^{-}$embryos. If $U b x^{+}$has not acted on $S c r$ early in embryogenesis, $S c r$ becomes active later in development in $\mathrm{T} 2$ and $\mathrm{T} 3$, giving rise to the transformations of $\mathrm{T} 2$ and $\mathrm{T} 3$ to $\mathrm{T} 1$ seen in $U b^{-}$clones in adults. Thus, the effects of an early regulatory interaction may become apparent only much later in devlopment.

\section{Scr protein is located within nuclei}

The spatial and temporal patterns of expression of several proteins that contain a homeodomain have been analyzed to date. These include Ultrabithorax (White and Wilcox 1984; Beachy et al. 1985), fushi tarazu (Carroll and Scott 1985), engrailed (DiNardo et al. 1985), Antennapedia (Carroll et al. 1986b; Wirz et al. 1986), caudal (MacDonald and Struhl 1986), and even-skipped (Frasch et al. 1987). All of these proteins are found predominantly within nuclei. Since the homeodomain has protein sequence homology to a class of bacterial DNAbinding proteins (Laughon and Scott 1984) and to the transcription-regulating products of the yeast $M A T$ locus (Laughon and Scott 1984; Shephard et al. 1984), it 
was hypothesized that genes containing a homeobox regulate the expression of other genes by virtue of their products' capacity to bind DNA. The nuclear location of Scr protein is also consistent with this hypothesis.

\section{Materials and methods}

Isolation of the Scr cDNA clone

A cDNA library prepared from three 12 -hr embryonic RNA in the $\lambda$ gt 10 vector (generously provided by Drs. L. Kauvar and T. Kornberg) was used. Phages were plated on LE392 bacteria at a density of $20-25 \times 10^{3}$ pfu per $150-\mathrm{mm}$ plate. A $1.8-\mathrm{kb}$ genomic DNA BamHI restriction fragment containing Scr coding region $5^{\prime}$ to the homeobox sequences (Harding et al. 1985) was excised from phage $\lambda$ A553 (Scott et al. 1983) for use as the probe. The fragment was labeled with ${ }^{32} \mathrm{P}$ according to the protocol of Feinberg and Vogelstein $(1983,1984)$ with random primers. Thirty plates were screened, equaling a population of approximately $7 \times 10^{5}$ phages. Screening was carried out on nitrocellulose filters as described by Benton and Davis (1977). A 3.9-kb Scr cDNA clone was obtained (Fig. 1b).

\section{Gene fusion constructions}

The 1.9-kb XhoI-SacII restriction fragment from the cDNA clone was subcloned into the pEMBL 19 plasmid vector (Dente et al. 1983). Methods were as described in Maniatis et al. (1982). The subcloned fragment was gel-purified and made blunt-ended with the Klenow fragment of DNA polymerase I. BamHI linkers were phosphorylated with T4 polynucleotide kinase and ligated to the fragment with T4 DNA ligase. After ligation, the fragment was digested with $B a m \mathrm{HI}$ and repurified on an agarose gel system. The linkered fragment was subcloned into pEMBL 19 , reisolated, and then inserted into the BamHI site at the $5^{\prime}$ end of the lac $Z$ gene in the pUR vectors 290, 291, and 292 (Ruther and Müller-Hill 1983). The vectors join the insert to lac $Z$ in all three possible reading frames. Inserts in the correct orientation, based on the $S c r$ cDNA restriction map (Fig. lb), were identified for further tests.

\section{Expression and purification of $\beta$-galactosidase-Scr fusion proteins}

The pUR-Scr cDNA constructions were introduced into LM1035 bacteria, and small protein samples were prepared as follows: An overnight culture was diluted a hundredfold in 2XYT (Maniatis 1982), and incubated shaking at $37^{\circ} \mathrm{C}$ for $2 \mathrm{hr}$. Isopropyl $\beta$-D-thiogalactopyranoside (IPTG) was added to 250 $\mu \mathrm{M}$, and the cultures were shaken for $30 \mathrm{~min}$ more at $30^{\circ} \mathrm{C}$. The cells were pelleted in a microcentrifuge at $4^{\circ} \mathrm{C}$, then resuspended in $100 \mathrm{~mm}$ Cleland's Reagent (dithiothreitol, DTT), $2.0 \%$ sodium dodecyl sulfate (SDS), $80 \mathrm{~mm}$ Tris, $\mathrm{pH} 6.9,10 \%$ glycerol, and $0.004 \%$ bromophenol blue. The cells were lysed by heating at $100^{\circ} \mathrm{C}$ for $5 \mathrm{~min}$, the debris was removed by centrifugation, and one-tenth of the sample was electrophoresed per single lane of a $7.5 \%$ slab polyacrylamide gel. One set of lanes was stained with Coomassie Blue, and replicate lanes were blotted onto nitrocellulose and checked for the presence of a homeodomain using a polyclonal antibody directed against a synthetic oligopeptide (described in Carroll et al. 1986b). Immunoblotting procedures were the same as those described previously for other antibodies (Carroll and Scott 1985).

A large-scale preparation of the $S c r-\beta$-galactosidase hybrid protein was made by $\mathrm{S}-300$ chromatography of an ammonium sulfate fraction of a whole-cell lysate as described in Carroll and Laughon (1987). Fractions containing the fusion protein, as de- termined by electrophoresis of aliquots, were checked for the presence of hybrid protein with antibodies to the homeodomain and $\beta$-galactosidase.

\section{Production, purification, and assay of anti-Scr antibodies}

Antigen was prepared by pooling fusion protein-containing fractions, then adding ammonium sulfate to $25 \%$ saturation, and precipitating the protein in the cold for 2-3 hr. After centrifugation $(12,100 \mathrm{~g}, 10 \mathrm{~min})$, the pellet was resuspended in 150 $\mathrm{mM} \mathrm{NaCl}$, then combined in a ratio of $4: 5$, antigen to adjuvant. Rabbits were immunized with approximately $1 \mathrm{mg}$ of soluble antigen in complete Freund's adjuvant on day 0, and again with $500 \mu \mathrm{g}$ antigen on days 14 and 21 , and then in 1-month intervals thereafter. Rabbits were bled on day 28 and at monthly intervals thereafter and were finally exsanguinated. All injections were subcutaneous at multiple sites. Antisera were affinity purified essentially as described previously (Carroll and Scott 1985; Carroll et al. 1986a; Carroll and Laughon 1987).

\section{Immunofluorescence}

Drosophila embryos were dechorionated, permeabilized in heptane, fixed in formaldehyde, and devitellinized in heptane/ methanol as described by Karr and Alberts (1986). Embryos were stained with anti-Scr antibody at a concentration of 1 $\mu \mathrm{g} / \mathrm{ml}$; fluorescein-conjugated goat anti-rabbit $\operatorname{IgG}$ was used as the secondary antibody as described (Carroll and Scott 1985).

\section{Acknowledgments}

We thank Fran Storfer for her contributions to the early phases of this work, and Dr. Danny Brower for making available an Scr monoclonal antibody. Thanks to Dr. Thom Kaufman for Scr alleles, Dr. Jim Kennison for the $P C^{R 1}$ allele, and Vern Twombly for excellent technical assistance. We are grateful to Drs. Allen Laughon, Karla Kirkegaard, Michael Akam, and Alfonso Martinez-Arias for critiquing the manuscript and to Cathy S. Inouye for its preparation. The research was supported by National Institutes of Health (NIH) grant 18163 and a Searle Scholar Award to M.P.S. and by NIH postdoctoral fellowship GM-09756 to S.B.C.

\section{References}

Akam, M. 1983. The location of Ultrabithorax transcripts in Drosophila tissue sections. EMBO J. 2: 2075-2084.

- 1985. Segments, lineage boundaries and the domains of expression of homeotic genes. Philos. Trans. R. Soc. Lond. B. Biol. Sci. 312: 179-187.

Akam, M.E. and A. Martinez-Arias. 1985. The distribution of Ultrabithorax transcripts in Drosophila embryos. EMBO $\%$. 4: $1689-1700$.

Beachy, P.A., S.L. Helfand, and D.S. Hogness. 1985. Segmental distribution of bithorax complex proteins during Drosophila development. Nature 313: 545-551.

Bender, M., F.R. Turner, and T.C. Kaufman. 1987. A developmental genetic analysis of the gene Regulator of Postbithorax in Drosophila melanogaster. Dev. Biol. 119: 418-432.

Benton, W.D. and R.W. Davis. 1977. Screening $\lambda g t$ recombinant clones by hybridization to single plaques in situ. Science 196: $180-182$.

Bopp, D., M. Burri, S. Baumgartner, G. Frigerio, and M. Noll. 1986. Conservation of a large protein domain in the segmentation gene paired and in functionally related genes of Drosophila. Cell 47: 1033-1040. 
Cabrera, C.V., J. Botas, and A. Garcia-Bellido. 1985. Distribution of Ultrabithorax proteins in mutants of Drosophila bithorax complex and its transregulatory genes. Nature 318: $569-571$.

Capdevila, M.P., J. Botas, and A. Garcia-Bellido. 1986. Genetic interactions between the Polycomb locus and the Antennapedia and Bithorax complexes of Drosophila. Wilhelm Roux's Arch. Dev. Biol. 195: 417-432.

Carroll, S.B. and A. Laughon. 1987. Production and purification of polyclonal antibodies to the foreign segment of $\beta$-galactosidase fusion proteins. In Expression of cloned genes: $A$ practical approach(ed. D. Glover), IRL Press, (In press.)

Carroll, S.B. and M.P. Scott. 1985. Localization of the fushi tarazu protein during Drosophila embryogenesis. Cell 43: 47-57.

1986. Zygotically active genes that affect the spatial expression of the fushi tarazu segmentation gene during early Drosophila embryogenesis. Cell 45: 113-126.

Carroll, S.B., R.A. Laymon, M.A. McCutcheon, P.D. Riley, and M.P. Scott. 1986a. The localization and regulation of Antennapedia protein expression in Drosophila embryos. Cell 47: 113-122.

Carroll, S.B., P.D. Riley, M.W. Klymkowsky, J. Van Blerkom, J. Stewart, and M.P. Scott. 1986b. Localization of homoeodomain-containing proteins using antibodies against a synthetic oligopeptide. Symp. Soc. Dev. Biol. 44: 257-270.

Chadwick, R. and W. McGinnis. 1987. Temporal and spatial distribution of transcripts from the Deformed gene of Drosophila. EMBO J. 6(3): 779-789.

Denell, R.E. 1982. Homoeosis in Drosophila: Evidence for a maternal effect of the Polycomb locus. Dev. Genet. 3: 103113.

Dente, L., G. Cesareni, and R. Cortese. 1983. pEMBL: A new family of single-stranded plasmids. Nucleic Acids Res. 11: $1645-1655$.

DiNardo, S., J.M. Kuner, J. Theis, and P.H. O'Farrell. 1985. Development of embryonic pattern in $D$. melanogaster as revealed by accumulation of the nuclear engrailed protein. Cell 43: 59-69.

Duncan, I.M. 1982. Polycomblike: A gene that appears to be required for the normal expression of the bithorax and antennapedia gene complexes of Drosophila melanogaster. Genetics 102: 49-70.

-1986. Control of bithorax complex functions by the segmentation gene fushi tarazu of Drosophila melanogaster. Cell 47: 297-309.

Duncan, I.M. and E.B. Lewis. 1982. Genetic control of body segment differentiation in Drosophila. In Developmental order: Its origin and regulation (ed. S. Subtelnyl, pp. 533-554. A.R. Liss, New York.

Feinberg, A.P. and B. Vogelstein. 1983. A technique for radiolabeling DNA restriction endonuclease fragments to high specific activity. Anal. Biochem. 132: 6-13.

- 1984. Addendum: A technique for radiolabeling DNA restriction endonuclease fragments to high specific activity. Anal. Biochem. 137: 266- 267.

Fjose, A., W.J. McGinnis, and W.J. Gehring. 1985. Isolation of a homoeo box-containing gene from the engrailed region of Drosophila and the spatial distribution of its transcripts. Nature 313: 284-289.

Frasch, M., T. Hoey, C. Rushlow, H. Doyle, and M. Levine. 1987. Characterization and localization of the even-skipped protein of Drosophila. EMBO J. 6: 749-759.

Garber, R.L., A. Kuroiwa, and W.J. Gehring. 1983. Genomic and cDNA clones of the homeotic locus Antennapedia in Drosophila. EMBO I. 2: 2027-2034.
Gergen, J.P. and E. Wieschaus. 1986. Localized requirements for gene activity in segmentation of Drosophila embryos: Analysis of armadillo, fused, giant, and unpaired mutations in mosaic embryos. Wilhelm Roux's Arch. Dev. Biol. 195: 4962.

Hafen, E., A. Kuroiwa, and W.J. Gehring. 1984a. Spatial distribution of transcripts from the segmentation gene fushi tarazu of Drosophila, Cell 37: 825-831.

Hafen, E., M. Levine, and W.J. Gehring. 1984b. Regulation of Antennapedia transcript distribution by the bithorax complex in Drosophila. Nature 307: 287-289.

Harding, K., C. Wedeen, W. McGinnis, and M. Levine. 1985. Spatially regulated expression of homeotic genes in Drosophila. Science 229: 1236-1242.

Harding, K., C. Rushlow, H.J. Doyle, T. Hoey, and M. Levine. 1986. Cross-regulatory interactions among pair-rule genes in Drosophila. Science 233: 953-959.

Hazelrigg, T. and T.C. Kaufman. 1983. Revertants of dominant mutations associated with the Antennapedia gene complex of Drosophila melanogaster. Genetics 105: 581-600.

Ingham, P.W. 1985. Genetic control of the spatial pattern of selector gene expression in Drosophila. Cold Spring Harbor Symp. Quant. Biol. 50: 201-208.

Ingham, P.W. and A. Martinez-Arias. 1986. The correct activation of Antennapedia and bithorax complex genes requires the fushi tarazu gene. Nature 324: 592-597.

Ingham, P.W., K.R. Howard, and D. Ish-Horowicz. 1985a. Transcription pattern of the Drosophila segmentation gene hairy. Nature 318: 439-445.

Ingham, P.W., A. Martinez-Arias, P.A. Lawrence, and K. Howard. 1985b. Expression of engrailed in the parasegment of Drosophila. Nature 317: 634-636.

Ingham, P.W., D. Ish-Horowicz, and K.R. Howard. 1986. Correlative changes in homoeotic and segmentation gene expression in Krüppel mutant embryos of Drosophila. EMBO $/$. 135: 144.

Jäckle, H., D. Tantz, R. Schuh, E. Seifert, and R. Lehmann. 1986. Cross-regulatory interactions among the gap genes of Drosophila. Nature 324: 668-670.

Karr, T.L. and B.M. Alberts. 1986. Organization of the cytoskeleton in early Drosophila embryos. I. Cell Biol. 102: 14891504.

Kaufman, T.C. 1983. The genetic regulation of segmentation in Drosophila melanogaster. In Time, space and pattern in embryonic development, pp. 365-383. A.R. Liss, Inc., New York.

Kaufman, T.C. and M.K. Abbott. 1984. Homoeotic genes and the specification of segmental identity in the embryo and adult thorax of Drosophila melanogaster. In Molecular aspects of early development (ed. G.M. Malacinski and W.H. Klein), pp. 189-218. Plenum Press, New York.

Kaufman, T.C., R. Lewis, and B. Wakimoto. 1980. Cytogenetic analysis of chromosome 3 in Drosphila melanogaster. The homoeotic gene complex in polytene chromosome interval 84A,B. Genetics 94: 115-133.

Kennison, J.A. and M.A. Russell. 1987. Dosage-dependent modifiers of homoeotic mutations in Drosophila melanogaster. Genetics 116: 75-86.

Kilchherr, F., S. Baumgartner, D. Bopp, E. Frei, and M. Noll. 1986. Isolation of the paired gene of Drosophila and its spatial expression during early embryogenesis. Nature 321: 493-499.

Knipple, D.C., E. Seifert, U.B. Rosenberg, A. Preiss, and H. Jäckle. 1985. Spatial and temporal patterns of Krüppel gene expression in early Drosophila embryos. Nature 317: 4044. 
Kornberg, T., I. Siden, P.O.'Farrell, and M. Simon. 1985. The engrailed locus of Drosophila: In situ localization of transcripts reveals compartment-specific expression. Cell 40: $45-53$.

Kuroiwa, A., U. Kloter, P. Baumgartner, and W.J. Gehring. 1985. Cloning of the homeotic Sex combs reduced gene in Drosophila and in situ localization of its transcripts. EMBO $/$. 4: 3757-3764.

Laughon, A. and M.P. Scott. 1984. Sequence of a Drosophila segmentation gene: Protein structure homology with DNAbinding proteins. Nature 310: 25-31.

Laughon, A., S.B. Carroll, F.A. Storfer, P.D. Riley, and M.P. Scott. 1985. Common properties of proteins encoded by the Antennapedia complex genes of Drosophila melanogaster. Cold Spring Harbor Symp. Quant. Biol. 50: 253-262.

Lehmann, R. and C. Nüsslein-Volhard. 1987. hunchback, a gene required for segmentation of an anterior and posterior region of the Drosophila embryo. Dev. Biol. 119: 402-417.

Levine, M., E. Hafen, R.L. Garber, and W.J. Gehring. 1983. Spatial distribution of Antennapedia transcripts during Drosophila development. EMBO /. 2: 2037-2046.

Lewis, E.B. 1978. A gene complex controlling segmentation in Drosophila. Nature 276: 565-570.

Lewis, R.A., B.T. Wakimoto, R.E. Denell, and T.C. Kaufman. 1980. Genetic analysis of the Antennapedia gene complex (ANT-C) and adjacent chromosomal regions of Drosophila melanogaster. II. Polytene chromosome segments 84A84B1,2. Genetics 95: 383-397.

MacDonald, P.M., P.W. Ingham, and G. Struhl. 1986. Isolation, structure, and expression of evenskipped: A second pair-rule gene of Drosophila containing a homeobox. Cell 47: 721734.

Maniatis, T., E.F. Fritsch, and J. Sambrook. 1982. Molecular cloning: A laboratory manual. Cold Spring Harbor Laboratory, Cold Spring Harbor, New York.

Martinez-Arias, A. 1986. The Antennapedia gene is required and expressed in parasegments 4 and 5 of the Drosophila embryo. $E M B O /$. 5: 135-141.

Martinez-Arias, A. and P.A. Lawrence. 1985. Parasegments and compartments in the Drosphila embryo. Nature 313: 639642.

Martinez-Arias, A., P.W. Ingham, M. Scott, and M.E. Akam. 1987. The spatial and temporal deployment of $D f d$ and $S c r$ transcripts throughout development of Drosophila. Development (in press).

McGinnis, W., R.L. Garber, J. Wirz, A. Kuroiwa, and W.J. Gehring. 1984a. A homologous protein-coding sequence in Drosophila homoeotic genes and its conservation in other metazoans. Cell 37: 403-408.

McGinnis, W., M. Levine, E. Hafen, A. Kuroiwa, and W.J. Gehring. 1984b. A conserved DNA sequence in homeotic genes of the Drosophila Antennapedia and bithorax complexes. Nature 308: 478-433.

Morata, G. and S. Kerridge. 1981. Sequential functions of the bithorax complex of Drosophila. Nature 290: 778-781.

Nüsslein-Volhard, C. and E. Wieschaus. 1980. Mutations affecting segment number and polarity in Drosophila. Nature 287: 795-801.

Petschek, J.P., N. Perrimon, and A.P. Mahowald. 1987. Regionspecific defects in 1(1) giant enbryos of Drosophila melanogaster. Dev. Biol. 119: 175-189.

Raff, R.A. and T.C. Kaufman. 1983. Embryos, genes, and evolution. Macmillan, New York.

Regulski, M., N. McGinnis, R. Chadwick, and W. McGinnis. 1987. Developmental and molecular analysis of Deformed: A homeotic gene controlling Drosophila head development.
EMBO J. 6: 767-777.

Rüther, V. and B. Müller-Hill. 1983. Easy identification of cDNA clones. $E M B O$ I. 2: 1791-1794.

Sanchez-Herrero, E., I. Vernos, R. Marco, and G. Morata. 1985. Genetic organization of Drosophila bithorax complex. Nature 313: 108-113.

Sato, T. and R.E. Denell. 1985. Homoeosis in Drosophila: Anterior and posterior transformations of Polycomb lethal embryos. Dev. Biol. 110: 53-64.

Sato, T., P.H. Hayes, and R.E. Denell. 1985. Homoeosis in Drosophila: Roles and spatial patterns of expression of the Antennapedia and Sex combs reduced loci in embryogenesis. Dev. Biol. 111: 171-192.

Scott, M.P. and A.J. Weiner. 1984. Structural relationships among genes that control development: Sequence homology between the Antennapedia, Ultrabithorax, and fushi tarazu loci of Drosophila. Proc. Natl. Acad. Sci. 81: 4115-4119.

Scott, M.P., A.J. Weiner, B.A. Polisky, T.I. Hazelrigg, V. Pirrotta, F. Scalenghe, and T.C. Kaufman. 1983. The molecular organization of the Antennapedia locus of Drosophila. Cell 35: 763-776.

Shepherd, J.C., W. McGinnis, A.E. Carrasco, E.M. DeRobertis, and W.J. Gehring. 1984. Fly and frog homoeo domains show homologies with yeast mating type regulatory proteins. $\mathrm{Na}$ ture 5972: 70-71.

Struhl, G. 1981a. A homoeotic mutation transforming leg to antenna in Drosophila. Nature 292: 635-638.

$-1981 \mathrm{~b}$. A gene product required for correct initiation of segmental determination in Drosophila. Nature 293: 3641.

1982. Genes controlling segmental specification in the Drosophila thorax. Proc. Natl. Acad. Sci. 79: 7380-7384.

- 1983. Role of the $\mathrm{esc}^{+}$gene product in ensuring the selective expression of segment-specific homeotic genes in Drosophila. J. Embryol. Exp. Morphol. 76: 297-331.

Struhl, G. and M. Akam. 1985. Altered distributions of Ultrabithorax transcripts in extra sex combs mutant embryos of Drosophila. EMBO J. 4: 3259-3264.

Struhl, G. and R.A.H. White. 1985. Regulation of the Ultrabithorax gene of Drosophila by other bithorax complex genes. Cell 43: 507-519.

Tautz, D., R. Lehmann, H. Schnürch, R. Schuh, E. Seifert, A. Kienlin, K. Jones, and H. Jäckle. 1987. Finger protein of novel structure encoded by hunchback, a second member of the gap class of Drosophila segmentation genes. Nature 327: 383-389.

Tokunaga, C. 1972. Autonomy or nonautonomy of gene effects in mosaics. Proc. Nat1. Acad. Sci. 69: 3283-3286.

Turner, F.R. and A.P. Mahowald. 1977. Scanning electron microscopy of Drosophila melanogaster embryogenesis. II. Gastrulation and segmentation. Dev. Biol. 57: 403-416.

- 1979. Scanning electron microscopy of Drosophila melanogaster embryogenesis. III. Formation of the head and caudal segments. Dev. Biol. 68: 96-109.

Wakimoto, B.T. and T.C. Kaufman. 1981. Analysis of larval segmentation in lethal genotypes associated with the Antennapedia gene complex in Drosophila melanogaster. Dev. Biol. 81: 51-64.

Wedeen, C., K. Harding, and M. Levine. 1986. Spatial regulation of Antennapedia and bithorax gene expression by the Polycomb locus in Drosophila. Cell 44: 739-748.

White, R.A.H. and R. Lehmann. 1986. A gap gene, hunchback, regulates the spatial expression of Ultrabithorax. Cell 47: $311-321$.

White, R.A.H. and M. Wilcox. 1984. Protein products of the bithorax complex in Drosophila. Cell 39: 163-171. 
Riley et al.

1985. Regulation of the distribution of Ultrabithorax proteins in Drosophila. Nature 318: 563-567.

Wieschaus, E., C. Nüsslein-Volhard, and H. Kluding. 1984. Krüppel, a gene whose activity is required early in the zygotic genome for normal embryonic segmentation. Dev. Biol. 104: 172-186.

Wirz, J., L.I. Fessler, and W.J. Gehring. 1986. Localization of the Antennapedia protein in Drosophila embryos and imaginal discs. EMBO I. 5: 3327-3334. 


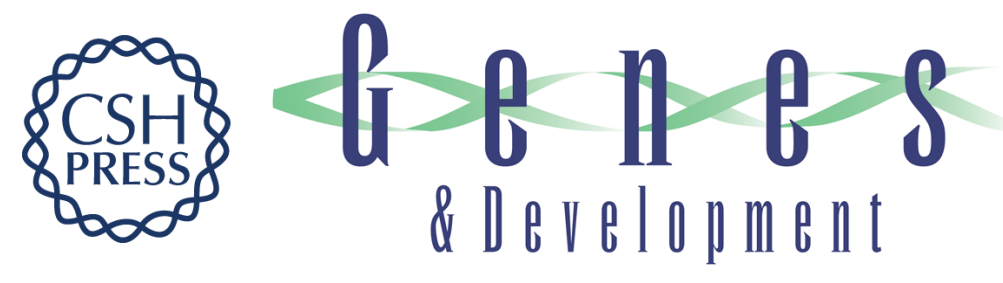

\section{The expression and regulation of Sex combs reduced protein in Drosophila embryos.}

P D Riley, S B Carroll and M P Scott

Genes Dev. 1987, 1:

Access the most recent version at doi:10.1101/gad.1.7.716

References This article cites 82 articles, 13 of which can be accessed free at: http://genesdev.cshlp.org/content/1/7/716.full.html\#ref-list-1

License

Email Alerting

Receive free email alerts when new articles cite this article - sign up in the box at the top Service right corner of the article or click here.

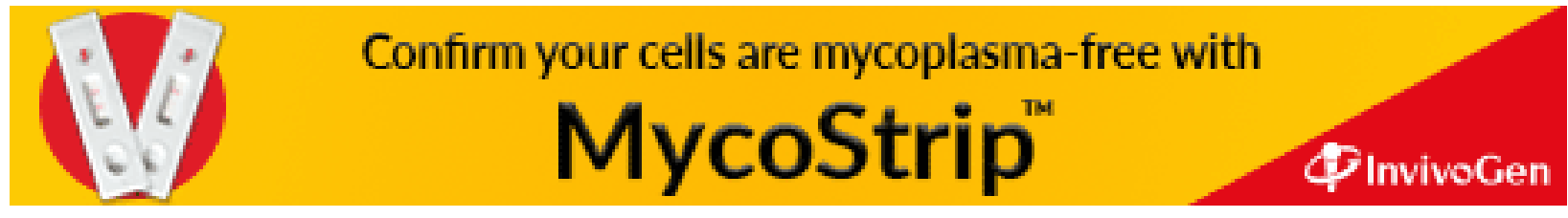

